\title{
Microwaves as a Humidity Measurement Device for Casted Moulds
}

\section{Jan Novotný, Petr Majrich}

Fakulta výrobních technologií a managementu, Univerzita J. E. Purkyně v Ústí nad Labem, 40001 Ústí nad Labem. Česká republika. E-mail: novotny@fvtm.ujep.cz, majrich@fvtm.ujep.cz

Thesis is interested in accurately detect moisture inside of plaster moulds, that will be measured by microwaves apparatus. Part of the thesis is also construction and assembly of the stable apparatus, so that it is possible to monitor the effects of microwaves on a plaster sample, then evaluate the moisture content of the sample and compare it with the weight test. The actual moisture measurement will be performed in several ways, such as by measuring the reflection or attenuation of electromagnetic waves. The result of this thesis will be a graphical representation of moisture to measurable variables relationships, gained from the microwave apparatus.

Plaster moulds are quite known, but casting technology requires from plaster moulds not only dimensional accuracy after drying, but as well surface smoothness, resistance to cracking upon drying and sufficient strength and breathability, or minimal gas evolution during casting. The presence of water during the casting process is not very welcome phenomenon. It is therefore very important to set correctly dry form, otherwise it may happen that the moulds can be during casting destroyed, or cast alloy can create a casting bubble by the influence of moisture in the form. That means discarding of the products.

Keywords: microwaves, plaster mold, dielectric properties

\section{References}

[1] BRŮNA, M., KUCHARČIK, L., SLADEK, A. (2013). Complex evaluation of porosity in A356 aluminium alloy using advanced porosity module. In Manufacturing Technology, Vol. 13, FVTM UJEP, Ústí nad Labem, ISSN 1213-2489.

[2] ČERNOHORSKÝ, D., RAIDA, Z. (1999). Analýza a optimalizace mikrovlnných struktur, VUTIUM, Brno. ISBN 80-214-1512-6

[3] LOUDA, J., BERAN, J., ŠTOLPA, M. (1967). Měření vlhkosti a obsahu vody pomocí mikrovln. Čs VTS, Ústí nad Labem..

[4] LYSOŇKOVÁ, I. (2012). Vliv formy k odlévání na strukturu slitiny AlCu4MgMn, Bakalárská práce, FVTM, UJEP, Ústí nad Labem

[5] MAIN, I. G. (1990). Kmity a vlny ve fyzice, Československé akademie věd Praha.

[6] NOVÁK, D., PAVLOVKIN, J.,KUBOVSKÝ, I.,ĎURIŠ, M. (2014). Elektrotechnika Belianum Univerzity Mateja Bela v Banskej Bystrici, ISBN 978-80-557-0777-8.

[7] PAUER, J. (2015). Měření vlhkosti odlévacích forem pomocí mikrovln, Bakalářská práce, FVTM, UJEP, Ústí nad Labem

[8] VALAŠEK, P., MULLER, M. (2012). Polymeric particle composites with filler saturated matrix. Manufacturing Technology, Ústí nad Labem, Voume 12. ISSN 1213-2489 